\title{
COMPARISON MUT'AH MARRIAGE ACCORDING TO ISLAMIC LAW AND NATIONAL LAW
}

\author{
Idrus Umarama \\ Master of Law UNISSULA \\ idrus.umarama96@gmail.com \\ Agus Hamzah \\ Master of Law UNISSULA \\ aguslaw3000@gmail.com \\ Jamaludin Al Ashari \\ Master of Law UNISSULA \\ jamalsala3@gmail.com \\ Arie Widyantoro \\ Master of Law UNISSULA \\ arie.aw.09@gmail.com \\ Faradina Mar'atus Shofia \\ Master of Law UNISSULA \\ faradiamafia@gmail.com
}

\begin{abstract}
Mut'ah marriage or temporary marriage or what is known as contract marriage is a phenomenon that often occurs in Indonesia, this problem must be anticipated because it is detrimental to women and has been forbidden by the Indonesian Ulama Council. The research method used is a normative juridical approach. Normative research or also known as literature law research is legal research carried out by examining library materials or secondary data. The results of the research found stated that Mut'ah marriage is temporary marriage, the Prophet Muhammmad S.A.W has justified the mut'ah marriage for three days and after that the Prophet forbade it forever. Here the Apostle once allowed it at a time which might have taken the form of an emergency as it was permissible to eat carcass meat, if there were no other foods under compulsion.
\end{abstract}

Keywords: Islamice Law; Mut'ah Marriage; National Law.

\section{A. INTRODUCTION}

Marriage in Indonesia can be seen from the point of view of Islamic law and national law (positive). The two cannot be separated, two things that have become one in positive law, Act No. 1 of 1974 concerning 
Marriage. ${ }^{1}$ An act of marriage or new marriage is said to be a legal act (according to law) if it is carried out according to the applicable legal provisions in a positive way, the legal provisions governing the marriage procedures that are justified by law are as regulated in the Marriage Law (UU. .1 of 1974). Marriage with such a new procedure has a legal effect (i.e. the result which has the right to legal recognition and protection). ${ }^{2}$

The law that applies to all Indonesian citizens regarding marriage is regulated in Law Number 1 of 1974 jo. Government Regulation Number 9 of 1975 refers to the laws of each religion and the beliefs of its adherents (Article 2 of Law Number 1 of 1974 in conjunction with Article 10 paragraph (3) of Government Regulation Number 9 of 1975). Thus, the law is a unification that fully respects the existence of variations based on religion and belief in the One Godhead, so that there is no marriage outside the law of each religion and belief that is not in accordance with the 1945 Constitution. the amendment results. ${ }^{3}$

In the Al Qur'an Allah says that marriage is one of the sunnatullah. Living in pairs or matchmaking is the instinct of all creatures, including humans. Allah does not want to make humans like other creatures who live freely according to their instincts and have anarchical relationship between male and female and there are no rules that govern it. ${ }^{4}$ In order for the heart to be united, one must also have one belief and the goal of facing it. Religious creed is the deepest and most comprehensive thing in building the soul, influencing it, shaping its feelings, limiting its responses and determining its course in all aspects of life. ${ }^{5}$

Literally the word marriage is an order addressed to all men and women in society. The basic ingredients of this reality (marriage) have been placed in men and women in the form of instinct, attraction, love, and goodness which are arranged according to the will of Allah S.W.T the Most Wise. ${ }^{6}$ The term "marriage" comes from Arabic, while according to the Indonesian term it is "marriage". Nowadays, there is a distinction between "married" and "married". But in principle, between "marriage" and "marriage" differ only in attracting our minds. When viewed from a legal perspective, it is clear that marriage is a sacred and noble contract between a man and a woman which is the cause of legal status as husband and wife

1 Akhmad Khisni, Kontroversi Putusan Mahkamah Konstitusi Tentang Perkawinan Di Bawah Tangan (Studi Tentang Hukum Perkawinan Antara Normatif dengan Empiiris untuk Menggali Maqashid-AL-Syari'ah dalam Upaya Mewujudkan fikih Indonesia), Jurnal Pembaharuan Hukum, Volume I No. 3 September-Desember 2014, page.307-317

2 Ibid.

3 Erni Agustina, akibat hukum hak mewaris anak hasil perkawinan siri Berbasis nilai keadilan, Jurnal Pembaharuan Hukum, Volume II No. 2 Mei-Agustus 2015, page.381-390

4 Djamaan Nur, Fikih Munakahat, Dina Utama, Semarang, 1993, page.5

5 Sayid Outhb, Tafsir Fi Zhilalil Qur'an Di Bawah Naungan A/-Quran Jilid 2, Gema Insani, Jakarta, 2000, page. 3

6 Husain Ansarian, Struktur Keluarga Islam, Pustaka Intermasa, Jakarta, 2000, page.8. 
and legalization of sexual relations with the aim of achieving a sakinah family, full of love, virtue, and mutuality. sympathize. ${ }^{7}$

Marriage, which in religious terms is called "nikah" means a contract that legalizes association and limits the rights and obligations of men and women who are not Muslim. ${ }^{8}$ Allah has created man and woman so that they can relate to each other, love each other, produce offspring, and live side by side in peace and prosperity according to Allah's guidance and the guidance of the Prophet. Our Master Muhammad [s] ordered Muslims to marry as soon as he was able. The family is the core of Islamic society. Only marry as a way to form this smallest institution of society. Meanwhile, intimate relations outside of marriage are cursed and forbidden. In accordance with the word of Allah SWT (Surah Al Isra: 32) which means: "And do not approach adultery, because in fact adultery is a heinous act and the worst way".

It is quite logical that Islam stipulates various provisions to regulate the functioning of the family so that with this legal marriage both husband and wife can obtain peace, love, security and kinship ties. These elements are indispensable for achieving the greatest goal of marriage, namely worship of Allah. Worship here does not only mean mere ritual utterances such as sexual relations between husband and wife, but in essence includes various good deeds in all aspects of life.

The ultimate goal of marriage is a goal far greater than the sheer desire of lust. They can learn to respect each other, love Allah and their families and for each other, and overcome their difficulties and shortcomings. The purpose of the second marriage is to meet the basic biological needs of humans in order to procreate. Children are expressions of motherhood and fatherhood. Islam pays attention to the possibility of providing a healthy and comfortable environment to raise children for their descendants.

The Prophet Muhammad saw that marriage for a Muslim is half of the teachings of religion because this marriage will protect a person from mental confusion, adultery, and actions that will lead to various other crimes.

The understanding of the meaning of marriage in Islamic law is very broad. This breadth is in line with people's lives throughout the ages and in every place. The forms and types of marriage that live and grow in the midst of society are quite diverse, both types and forms of marriage. The form and type of marriage can be classified into 2 (two) major groups, namely: ${ }^{9}$

1. Marriage that is allowed. For example homogamy, in homogamy the marriage between men and women both have almost the same position. In Islamic law, equality of position or equality between husband and wife

7 Sudarsono, Pokok-pokok Hukum Islam, Rineka Cipta, Jakarta, 1993, page.188.

8 Syafrudin Yudowibowo, Tinjauan Hukum Perkawinan Di Indonesia Terhadap Konsep Kafa'ah Dalam Hukum Perkawinan Islam, Yustisia, Vol.1 No.2 Mei-Agustus 2012, page.98-109

9 Ibid., page. 229-230. 
is based on Islamic principles, namely the factor of devotion to Allah SWT.

2. Prohibited marriages. For example mut'ah marriage or contract marriage which means a man who is married to a woman who is limited by a certain time such as one month, two months, or in a certain time unit..

There are actually many kinds of prohibited marriages, one of which is in the form of a contract marriage or in Islam it is often referred to as mut'ah marriage. In the early days of Islam, this mut'ah marriage or contract marriage was permitted when the condition of the Muslim faith was very shallow because it was still in the transition period from the era of ignorance to the era of Islam. Adultery is considered normal and innocent, in order to prevent greater harm to the personal condition of the friends, both due to travel and war, contract marriage is justified. After the Islamic law was perfect and the faith of the friends had been solid, the Prophet's permission to marry the contract was revoked.

The purpose of this paper is to identify and analyze the perspective of mutah marriage in the view of Islam and national law. This is because mut'ah marriage or contract marriage today is still practiced, from the top to the middle to lower classes and has become a prolonged controversy.

\section{B. RESEARCH METHODS}

The research method used is a normative juridical approach. Normative research or also known as literature law research is legal research carried out by examining library materials or secondary data, then to be applied to research problems, so that their presentation is based on principles and theories. theories and doctrines as well as applicable laws. The specification of this research is descriptive in accordance with the problems and objectives in the study. Research by describing a number of variables relating to the problem being researched. ${ }^{10}$

The legal materials used in this study consist of primary and secondary legal materials. Primary legal materials consist of statutory regulations, official records or treatises relating to this research. Meanwhile, secondary legal materials relate to legal materials that provide clarification to primary legal materials, such as books, literature, articles, papers and other materials taken from legal experts.

\section{RESULT AND DISCUSSION}

\section{The View of Islamic Law Regarding Mut'ah Marriage}

Contract marriage in Islam is called mut'ah which etymologically means "enjoyment and pleasure", so the purpose of the marriage is only to obtain sexual pleasure, on the other hand according to syara 'mut'ah, a man marries a woman in exchange for property (money) with a certain

10 Andri Winjaya Laksana, Suratman, Analisis Yuridis Penyidikan Tindak Pidana Pornografi Berdasarkan Undang-Undang Nomor 44 Tahun 2008 Di Era Digitalisasi, Jurnal Pembaharuan Hukum, Volume I No. 2 Mei-Agustus 2014, page.169-177 
time limit. In a mut'ah marriage, the period of marriage will end without divorce and there is no obligation for the man to give a donation, place to live and other obligations. This is of course very detrimental to women and their offspring. That is why a contract marriage is not allowed according to both religious law and state law. ${ }^{11}$

Mut'ah marriage or it is called a contract marriage is a marriage that is limited in time, so the time is only temporary or not forever. If the contract in the marriage has expired, the marriage will automatically cancel itself without having to be divorced first. Because in the implementation of the consent qabul in a contract marriage, it must be clearly stated the deadline for carrying out the marriage. So it is clear that this kind of marriage is very forbidden according to Islamic law because it is impermanent, namely for a time.

In fact, the phenomenon of contract marriage has been very common in any country. For example, in our own country, namely Indonesia, contract marriages are mostly carried out by indigenous women and foreign men. I don't know what they mean to do the contract marriage, what is clear is that it will be very detrimental, especially for women themselves. It is clear that these women also have to bear the shame as a result of the contract marriage they enter into, other than if they also bear children as a result of the contract marriage. so when the time for marriage is over, how can the woman support the child in her womb until she grows up.

As one of the most appropriate solutions to prevent contract marriage is to provide a clear and clear understanding of the meaning of contract marriage itself, especially for women who are very disadvantaged. Maybe in modern times, a small proportion of people in our country do not understand that contract marriage is actually forbidden.

In the early days of Islam, this mut'ah marriage or contract marriage was permitted when the condition of Muslim faith was still very shallow because it was still in the transition period from the era of ignorance to the era of Islam. As was understandable in the era of ignorance. Adultery is considered normal and innocent. In order to avoid greater harm to the personal condition of the compatriots, whether due to travel (travelers) or wars (ghazwah), contractual marriage is justified. After the Islamic syari'ah was perfect and the faith of the friends was solid, the permission to marry the contract was revoked by Rasullulah S.A.W. The prohibition of mut'ah marriage or contract marriage only applies to the Sunni school of thought, while this kind of marriage is permitted even though contract marriages are very rare. ${ }^{12}$

11 Sri Hariati, Kawin Kontrak Menurut Agama Islam, Hukum Dan Realita Dalam Masyarakat, Jurnal Hukum JATISWARA, Vol 30 No 1 (2015), page.93-102

12 Amiur Nuruddin, Hukum Perdata Islam di Indonesia, Prenada Media, Jakarta, 2014, page.153-154 
Mut'ah marriage or temporary marriage or what is known as a contract marriage. The definition is the marriage of a man and woman for fun or intercourse for a while. For example one month, two months, one year or more. Without a dowry, there is no iddah and no inheritance. $^{13}$

Hussein Bahreisj also explained that: mut'ah marriages or contract marriage, which is a temporary marriage according to Muslim hadith that the Prophet justified the mut'ah marriage for three days and after that the Prophet forbade it forever. Here the Apostle once allowed it at a time which might have taken the form of an emergency as if it was possible to eat a carcass, if there were no other foods in a state of compulsion. After that the Prophet firmly stated the prohibition of mut'ah marriage or contract marriage during the Khaibar war which he forbade forever. In that case the Caliph Umar once punished the perpetrators of mut'ah marriages with stoning because they were classified as adultery.

In addition to that the prohibition of mut'ah marriage or contract marriage is also conveyed by several hadiths, including: From Abu Abdillah he said: "Ali has explained it from the Prophet Muhammad S.A.W, that mut'ah marriages has been abolished (not enforced). ${ }^{14}$ Sending from Iyas bin Salamah from his father he said: "In the year of Authas or the year of the conquest of the city of Mecca. Rasulullah S.A.W gave mercy to do mut'ah marriage for 3 days then he forbade it. ${ }^{15}$

From Zuhri he said: "Once we were beside Umar bin Abdul Aziz, then we discussed mut'ah marriage with women. Then a man named Rabi 'bin Sabrah said: "I witnessed that my father told a hadith: In fact the Prophet Muhammad forbade the Hajj Wada". " This hadith was issued by Bukhari, Muslim, Nasaai, and Ibn Majah with the same and more perfect and also narrated by Ahmad. ${ }^{16}$

It is narrated from Sabrah bin Ma'bad Al Juhaini that: "Verily Rasulullah S.A.W has forbidden mut'ah to women". In the Sahih Muslim book there is an additional sentence: "In the era of the conquest of the city of Mecca". ${ }^{17}$ Rasulullah prevented us from doing this, then Rasulullah allowed us to marry a woman with a piece of cloth (to a certain extent) after which he read: "Ya ayyuhal ladzina amanu la tuharrimu thaiyibati ma ahallallahu lakum". Meaning: "O believers, do not forbid the good things that Allah has allowed for you". Ziwaj mut'ah is also called ziwaj munqathi', called mut'ah because the man only enjoys a woman for a while. Yahya conveyed to me (hadith) from Malik from Ibn Shihab from Urwa ibn az Zubayr that Khawla ibn Hakim came to Umar ibn al-Khatab

13 Warno Hamid, Merajut Perkawinan Harmonis, Insan Cendekia, Surabaya, 1999, page.27

14 Achmad Sunarto, Shahih Bukhari Juz VII, Asy Syifa', Semarang, 1993, page. 46

15 Muhammad Nashiruddin Al Abani, Mukhtasar Shahih Muslim, Al Maktab Al Islam, Beirut, 2003, page. 567-568

16 Bey Arifin, Terjamah Sunan Abi Daud, Asy Syifa, Semarang, 1992, page.21

17 Muhammad Nashiruddin Al Abani, Shahih Sunan Abu Daud, Maktabah Al Ma'arif Riyadh, Jakarta, 1998, page.807 
and said: "Rabi'a ibn Umayya did a mut'ah marriage with a woman and she became pregnant by him. ". Umar ibn al-Khattab came out in shock and grabbed his robe saying: "This mut'ah marriages, if only I found it, I would order to stone it (throw stones) and finish it with it". ${ }^{18}$

The majority of scholars consisting of friends and tabiin have maintained this prohibition, they have practiced it and then narrated it to us. ${ }^{19}$ So if now there are people who do mut'ah marriage or contract marriage then the law is haram, Islam is not justified, it is not justified by the Prophet Muhammad, and not justified by Allah.

Islam wants to build a prosperous society. A mut'ah marriage or a contract marriage if allowed can cause more problems than it can get. If the contract marriage is not prohibited it will lead to prostitution. The scholars have agreed to state that contract marriage is haraam. Only Abdullah bin Abbas's opinion contradicts this agreement. But as soon as he saw the gravity of the situation and people were abusing this contract marriage which was only allowed in the turbulent battle zone environment, he soon banned it $\{$ H.R Bukhari\}. However, some scholars of the syi'ah mazhab still allow kawin mut'ah to this day even though it is rarely practiced. ${ }^{20}$ According to the syi'ah mazhab itself, the legal consequences of contract marriage are: ${ }^{21}$

a. If the dowry is not stated but the time limit is stated, the marriage contract is canceled but if the dowry is stated and the time limit is not stated, then the marriage is changed to ordinary marriage;

b. Children who are born become children;

c. There is no divorce and no li'an;

d. There is no inheritance right between husband and wife;

e. Children have the right to inherit from their father-mother and fathermother rights to inherit from their children;

f. The iddah period is twice the menstrual period for those who are still practicing. And for those who do, but it turns out that their menstruation stops, the iddah period is 45 days.

In the book Wasail Asy-Shia: "It is not permissible to mut'ah with daughters before baligh without a guardian". It can be translated as: "All scholars of the Shia Ja'fariah consensus (ijma ') that a girl who is nine years old is no longer a child, unless in her mind there is weakness, and if not, then she is already baligh when she is nine years old". Are there dangers and calamities greater than this? How could it not be, while a girl who is only nine years old does not go to school, but instead goes with someone who is going to commit adultery under the name of

18 Imam Malik Ibn Anas Penerjemah Dwi Surya Atmaja, Al-Muwatta' of Imam Malik Ibn Anas the First Formulatin of Islamic Law, Raja Grafindo Persada, Jakarta, 1992, page.291

19 Al Imam Muhammmad Asy Syukani, Nailul Authar VI, Asy Syifa, Semarang, 1994, page. 522

20 A. Rahman I.Doi, Penjelasan Lengkap Hukum-hukum Allah (Syariah), Raja Grafindo Persada, Jakarta, 2002, page.205

21 Sayid Sabiq, Fikih Sunnah, Alma'arif, Bandung, 1990, page.61 
marriage contra? Therefore, all Muslims should respond to this disaster whenever they find in their environment people who pollute them, namely people who legalize adultery with underage children while being hidden without the knowledge of their families.

Looking at the ways, motivations, and consequences contained in contract marriage, it is clear that women are disadvantaged in many ways. Even this marriage is believed to have opened up opportunities for trafficking of women and children. The presence of Islam frees women from all forms of oppression of the ignorant culture. Islam wants women to occupy a noble position. If history allows contract marriages in the beginning, it is because Islamic law is still in the process of being perfected. In fact, to prove that Islam is consistent with its mission (freeing women from forms of oppression), the Prophet finally prohibited contract marriage, however, if a woman has fallen into this marriage, then efforts must be made to encourage men to be responsible.

Apart from the above differences of opinion, what should be used as a guideline is that mut'ah marriage contradicts the meaning and purpose of marriage as in the marriage law, namely marriage is forever and aims to regenerate the offspring should be educated by both parents. As stated by syaltut, mut'ah marriage is far from the principle of marriage mentioned in the Al-Quran, which is the feeling of love and affection between husband and wife. This combination of love and affection produces a family, has children, and brings them together. ${ }^{22}$

\section{View of Mut'ah Marriage According to National Law}

In Indonesian Muslim society, there are three categories of law, namely syari'ah, figh and siyasah syar'iyah (al-qawanin), namely legislation made by the competent authority that is in accordance with or does not conflict with Islamic values. The prevailing power between the three is different, because they have different sources. Shari'ah is Islamic law product of revelation, which is eternal (qath'i) and universal, while fiqh is the law of the product of reason, reason works in an effort to understand maqashid al-syar'ah, the law of the product of revelation (syari'ah) in accordance with the context. time and place, so that it becomes a contextual law according to the needs of the Muslim community as the basis for the application of the law. ${ }^{23}$

A contract marriage or kawin mut'ah which is widely known in several regions in Indonesia is a marriage between two prospective brides and an agreement within a certain time. Because it was done underhandedly, this marriage was not registered with the competent authority. In law, a contract marriage is actually not permitted because it is in accordance with the provisions of Law No.1 of 1974 concerning

22 Nurlailiyah Aidatussholihah, Kawin Kontrak Di Kawasan Puncak Antara Normatif, Yuridis Dan Realita, Al-Ahwal, Vol. 5, No. 2, 2012, page.31-56

23 Akhmad Khisni, Hukum Islam dan Peradilan Agama di Indonesia, Cet. 1, Unissula Press, Semarang, 2011, page.45 
marriage. Article 1 of the Marriage Law states that: Perkawinan ialah ikatan lahir bathin antara seorang pria dengan seorang wanita sebagai suami istri dengan tujuan membentuk keluarga (rumah tangga) yang bahagia dan kekal berdasarkan Ketuhanan Yang Maha Esa. ${ }^{24}$

A marriage whose time limit is determined based on the agreement of the perpetrators in Indonesia is known as a contract marriage. In terms of fiqh it is known as mut'ah marriage.

Mut'ah marriage experienced ups and downs in the stipulation of the law, until finally it was forbidden forever. But the Shi'ah allow it. A contract marriage that is carried out has a negative impact or injustice for women and children who are born, therefore, as much as possible contract marriages are avoided. For this reason, it is necessary to raise awareness in society, especially women that they are one of Allah's noble creatures. She can live the same as men if she uses all the potential that exists in her, by studying knowledge. Because with science he can play a role in society and can be prevented from negative actions that harm himself and his children.

Rules In this case, at least four laws and regulations that apply legally (positively) in Indonesia regarding mut'ah marriage can be quoted as follows:

a. Pancasila, especially principle I, "Ketuhanan Yang Maha Esa" and principle II, "Kemanusiaan Yang Adil dan Beradab";

b. Amendments to the 1945 Constitution, chapter 31 on religion, Article 29 paragraph (1) and (2);

c. Article 1 of Law Number 1 Year 1974 concerning Marriage which states, "Perkawinan ialah ikatan lahir batin antara seorang pria dengan seorang wanita sebagai suami istri dengan tujuan membentuk keluarga (rumah tangga) yang bahagia dan kekal berdasarkan Ketuhanan Yang Maha Esa";

d. Article 2 of the Compilation of Islamic Law (KHI), states, "Perkawinan menurut Hukum Islam adalah pernikahan, yaitu akad yang sangat kuat atau mitsaqan galizan untuk mentaati perintah Allah dan melaksanakannya merupakan ibadah ". Also Article 3 which emphasizes, "Perkawinan bertujuan untuk mewujudkan kehidupan rumah tangga yang sakinah, mawaddah, dan rahmah."

Based on the four points above, the more clear the direction of policy and the interests of the government in realizing a harmonious and prosperous family by making a set of laws and regulations aimed at protecting all Indonesian people; with a theory that a country is said to have strong stability if it is supported by the existence of stable families or households. This will be difficult to materialize if the foundation of the family is built with a marriage such as mut'ah marriage. Therefore, the

24 Mutiara Citra, Tinjauan Yuridis Terhadap Kawin Kontrak Dalam Perspektif Hukum Perjanjian Dan Hukum Islam, JOM Fakultas Hukum, Volume III nomor 1, Februari 2016, page.2-16 
government should take firm steps against perpetrators of mut'ah marriage and unscrupulous persons from government agencies or outside government agencies who are involved in the occurrence of mut'ah marriage and the like. ${ }^{25}$

In law, a contract marriage is actually not permitted because it is in accordance with the provisions of Law No.1 of 1974 concerning marriage. Therefore a contract marriage is not a legal marriage because it is basically carried out not for the noble purpose of obeying God's commands and to form a happy family but only to fulfill purposes based on purely economic or biological interests. In addition, contract marriages violate the provisions of Law No. 1 of 1974 Article 2 paragraph (2). Likewise, it is important to remember that a contract marriage will harm the child that results from this marriage because the child does not have a status or a real father.

Regarding the termination of a contract marriage, it cannot be classified as a break-up of marriage as stated in Article 38 of the Marriage Law, where the break-up of a marriage can be caused by 3 things, namely: death, divorce, and court decisions. The termination of a contract marriage cannot be classified as the breakdown of a marriage due to divorce, because in essence, from the beginning, the marriage is considered invalid or in other words, there has never been a marriage. ${ }^{26}$

\section{CONCLUSION}

The purpose of this paper is to identify and analyze the perspective of mutah marriage in the view of Islam and national law and concluded that Mut'ah marriage is temporary marriage, the Prophet Muhammmad S.A.W has justified the mut'ah marriage for three days and after that the Prophet forbade it forever. Here the Apostle once allowed it at a time which might have taken the form of an emergency as it was permissible to eat carcass meat, if there were no other foods under compulsion. After that the Prophet firmly stated the prohibition of contract marriage during the Khaibar war which he forbade forever. in the marriage law stipulates that marriage is valid if it is carried out according to the law of each religion and belief. This means that if it is done not based on the religion and belief of each party, its legality will not be recognized legally until the Day of Judgment.

25 Muhammad Saleh Ridwan, Perkawinan Mut'ah Perspektif Hukum Islam dan Hukum Nasional, Jurnal Al-Qadāu, Volume 1 Nomor 1, 2014, page.36-47

26 Muhyidin, Navanya Gabriel Cuaca, Nikah Muth'ah (Kawin Kontrak) Dalam Perspektif Hukum Positif Indonesia Serta Akibat Hukum Atas Harta Perkawinan Dan Harta Waris, Diponegoro Private Law Review, VOL. 7 NO. 1 Februari 2020, page.732-742 
Idrus Umarama, Agus Hamzah, Jamaludin Al Ashari, Arie Widyantoro, Faradina Mar'atus Shofia

\section{BIBLIOGRAPHY}

\section{Book:}

A. Rahman I. Doi, 2002, Penjelasan Lengkap Hukum-hukum Allah (Syariah), Raja Grafindo Persada, Jakarta;

Achmad Sunarto, 1993, Shahih Bukhari Juz VII, Asy Syifa', Semarang;

Akhmad Khisni, 2011, Hukum Islam dan Peradilan Agama di Indonesia, Cet. 1, Unissula Press, Semarang;

Al Imam Muhammmad Asy Syukani, 1994, Nailul Authar VI, Asy Syifa, Semarang;

Amiur Nuruddin, 2014, Hukum Perdata Islam di Indonesia, Prenada Media, Jakarta;

Bey Arifin, 1992, Terjamah Sunan Abi Daud, Asy Syifa, Semarang;

Djamaan Nur, 1993, Fikih Munakahat, Dina Utama, Semarang;

Husain Ansarian, 2002, Struktur Keluarga Islam, Pustaka Intermasa, Jakarta;

Imam Malik Ibn Anas Penerjemah Dwi Surya Atmaja, 1992, Al-Muwatta' of Imam Malik Ibn Anas the First Formulatin of Islamic Law, Raja Grafindo Persada, Jakarta;

Muhammad Nashiruddin Al Abani, 1998, Shahih Sunan Abu Daud, Maktabah Al Ma'arif Riyadh, Jakarta;

Muhammad Nashiruddin Al Abani, 2003, Mukhtasar Shahih Muslim, Al Maktab Al Islam, Beirut;

Sayid Outhb, 2000, Tafsir Fi Zhilalil Qur'an Di Bawah Naungan Al-Quran Jilid 2, Gema Insani, Jakarta;

Sayid Sabiq, 1990, Fikih Sunnah, Alma'arif, Bandung;

Sudarsono, 1993, Pokok-pokok Hukum Islam, Rineka Cipta, Jakarta;

Warno Hamid, 1999, Merajut Perkawinan Harmonis, Insan Cendekia, Surabaya;

\section{Journal:}

Akhmad Khisni, Kontroversi Putusan Mahkamah Konstitusi Tentang Perkawinan Di Bawah Tangan (Studi Tentang Hukum Perkawinan Antara Normatif dengan Empiiris untuk Menggali Maqashid-AL-Syari'ah dalam Upaya Mewujudkan fikih Indonesia), Jurnal Pembaharuan Hukum, Volume I No. 3 September-Desember 2014;

Andri Winjaya Laksana, Suratman, Analisis Yuridis Penyidikan Tindak Pidana Pornografi Berdasarkan Undang-Undang Nomor 44 Tahun $2008 \mathrm{Di}$ Era Digitalisasi, Jurnal Pembaharuan Hukum, Volume I No. 2 MeiAgustus 2014; 
Idrus Umarama, Agus Hamzah, Jamaludin Al Ashari, Arie Widyantoro, Faradina Mar'atus Shofia

Erni Agustina, akibat hukum hak mewaris anak hasil perkawinan siri Berbasis nilai keadilan, Jurnal Pembaharuan Hukum, Volume II No. 2 MeiAgustus 2015;

Muhammad Saleh Ridwan, Perkawinan Mut'ah Perspektif Hukum Islam dan Hukum Nasional, Jurnal A/-Qadāu, Volume 1 Nomor 1 Tahun 2014;

Muhyidin, Navanya Gabriel Cuaca, Nikah Muth'ah (Kawin Kontrak) Dalam Perspektif Hukum Positif Indonesia Serta Akibat Hukum Atas Harta Perkawinan Dan Harta Waris, Diponegoro Private Law Review, VOL. 7 NO. 1 Februari 2020;

Mutiara Citra, Tinjauan Yuridis Terhadap Kawin Kontrak Dalam Perspektif Hukum Perjanjian Dan Hukum Islam, JOM Fakultas Hukum, Volume III nomor 1, Februari 2016;

Nurlailiyah Aidatussholihah, Kawin Kontrak Di Kawasan Puncak Antara Normatif, Yuridis Dan Realita, Al-Ahwal, Vol. 5, No. 2, 2012;

Sri Hariati, Kawin Kontrak Menurut Agama Islam, Hukum Dan Realita Dalam Masyarakat, Jurnal Hukum JATISWARA, Vol 30 No 1 (2015);

Syafrudin Yudowibowo, Tinjauan Hukum Perkawinan Di Indonesia Terhadap Konsep Kafa'ah Dalam Hukum Perkawinan Islam, Yustisia, Vol.1 No.2 Mei-Agustus 2012; 